\title{
The use of quantitative PCR with high resolution melting (qPCR-HRM) analysis to distinguish the Polish mild and yellowing pathotypes of Pepino mosaic virus (PepMV)
}

\author{
Zastosowanie techniki ilościowego PCR z analizą krzywych topnienia \\ (qPCR-HRM) do rozróżniania polskich łagodnych \\ i żółtaczkowych patotypów wirusa mozaiki pepino \\ (Pepino mosaic virus, PepMV)
}

Julia Minicka ${ }^{1 *}$, Beata Komorowska², Beata Hasiów-Jaroszewska ${ }^{1}$

\begin{abstract}
Summary
Pepino mosaic virus (PepMV) is a highly infectious virus causing significant losses in tomato greenhouse production worldwide. One of the characteristic symptoms is yellowing discolorations of leaf blades, which is often accompanied by damage of the fruits. It has been found that, two independent point mutations in the gene encoding the coat protein (CP) are responsible for the formation of yellowing symptoms: $\mathrm{G}_{463} \mathrm{AA} / \mathrm{A}_{463} \mathrm{AA}\left(155 \mathrm{aa}\right.$ ) and $\mathrm{GA}_{497} \mathrm{U} / \mathrm{GG}_{497} \mathrm{U}(166 \mathrm{aa})$ ), respectively. In our study, qPCR-HRM was used to distinguish mild and yellowing pathotypes. Appropriate primers, amplifying a fragment of the CP-encoding gene in which both yellowing mutations are located were designed. The analysis was carried out using 18 isolates originated from greenhouses in different region of Poland. Our experiments confirmed the effectiveness of the designed primers to differentiate the analyzed pathotypes. This technique is a valuable tool for detecting the diversity of PepMV.
\end{abstract}

Key words: Pepino mosaic virus, $\mathrm{CH} 2$ strain, yellowing pathotype, Solanum lycopersicum, qPCR-HRM

\section{Streszczenie}

Wirus mozaiki pepino (PepMV) jest groźnym patogenem powodującym znaczne straty w uprawie szklarniowej pomidora w wielu regionach świata. Jednym z charakterystycznych objawów obecności wirusa w roślinie są żółtaczkowe przebarwienia blaszek, którym często towarzyszy uszkodzenie owoców. Za ich powstawanie odpowiedzialne są dwie niezależne mutacje punktowe w genie kodującym białko płaszcza (CP): $\mathrm{G}_{463} \mathrm{AA} / \mathrm{A}_{463} \mathrm{AA}$ (155 aa) i $\mathrm{GA}_{497} \mathrm{U} / \mathrm{GG}_{497} \mathrm{U}$ (166 aa). W przeprowadzonych badaniach wykorzystano qPCR-HRM do rozróżniania łagodnych i żółtaczkowych patotypów. Zaprojektowano startery, amplifikujące fragment genu kodującego $\mathrm{CP}$, w którym znajdują się obie mutacje żółtaczkowe. Przeanalizowano 18 izolatów, pochodzących z obiektów szklarniowych na terenie całego kraju. Wykonane doświadczenia potwierdziły skuteczność zaprojektowanych starterów do różnicowania analizowanych patotypów. Technika ta może być z powodzeniem stosowana do rozróżniania łagodnych i żółtaczkowych patotypów PepMV na terenie naszego kraju.

Słowa kluczowe: Pepino mosaic virus, szczep CH2, patotyp żółtaczkowy, Solanum lycopersicum, qPCR-HRM

\footnotetext{
${ }^{1}$ Instytut Ochrony Roślin - Państwowy Instytut Badawczy

Zakład Wirusologii i Bakteriologii

Władysława Węgorka 20, 60-318 Poznań

${ }^{2}$ Instytut Ogrodnictwa, Zakład Fitopatologii

Konstytutcji 3 Maja 1/3, 96-100 Skierniewice

*corresponding author: J.Minicka@iorpib.poznan.pl

ORCID: 0000-0002-7773-9079
} 


\section{Wstęp / Introduction}

Wirus mozaiki pepino (Pepino mosaic virus, PepMV) (rodzaj Potexvirus, rodzina Alfaflexiviridae) jest jednym z najgroźniejszych wirusów, jakie obecnie porażają uprawy pomidora w wielu krajach Europy, Ameryce Północnej i Południowej oraz Chinach (French i wsp. 2001; Pospieszny i wsp. 2003; Maroon-Lango i wsp. 2005; Ling 2007; Moreno-Pérez i wsp. 2014). Od roku 2007 znajduje się on na liście A2 organizmów regulowanych w Unii Europejskiej 2004/200/EC według Europejskiej i Śródziemnomorskiej Organizacji Ochrony Roślin (EPPO). Wirus przenoszony jest mechanicznie $\mathrm{z}$ sokiem porażonych roślin, jak również w niewielkim stopniu przez mączliki, trzmiele, z nasionami $(0,026 \%)$ oraz z wodą (Córdoba-Sellés i wsp. 2007; Shipp i wsp. 2008; Hanssen i wsp. 2010; Schwarz i wsp. 2010; Mehle i wsp. 2014; Noël i wsp. 2014). PepMV powoduje szerokie spektrum objawów na porażonych roślinach, obejmujące: mozaiki o zróżnicowanym stopniu nasilenia, deformacje blaszek liściowych, silne przebarwienia liści i owoców, chlorozy, żółtaczki, pękanie i nekrozy owoców, a nawet zamieranie roślin (van der Vlugt i wsp. 2000; Roggero i wsp. 2001; Spence i wsp. 2006; Hasiów i wsp. 2008; Hasiów-Jaroszewska i wsp. 2009, 2013; Hanssen i Thomma 2010; Blystad i wsp. 2015). Na obecność i intensywność objawów chorobowych ma wpływ szczep wirusa (Hasiów-Jaroszewska i wsp. 2010), warunki środowiska (Spence i wsp. 2006) oraz występowanie izolatów w pojedynczej lub mieszanej infekcji (Hanssen i wsp. 2008, 2009). Dotychczas nie stwierdzono odmian pomidora odpornych na tego patogena. Genom wirusa stanowi pojedyncza nić RNA o dodatniej polarności, o długości około 6410-6412 nt. Cząstki PepMV są nitkowate o długości około 500-530 nm, typowe dla przedstawicieli rodzaju Potexvirus. Jak dotąd zidentyfikowano pięć szczepów wirusa: europejski (EU), peruwiański (LP), południowo-peruwiański (PES), amerykański 1 (US1) oraz chilijski 2 (CH2). Dynamiczne zmiany w strukturze europejskiej populacji wirusa w ostatnich latach doprowadziły do wzrostu liczebności izolatów należących do szczepów CH2, w stosunku do pozostałych szczepów (Ling 2007; Hanssen i wsp. 2008; Gómez i wsp. 2009; Tiberini i wsp. 2011; Ling i wsp. 2013). Również w polskiej populacji wirusa od roku 2005 obserwowana jest zdecydowana przewaga izolatów należących do tego szczepu (Minicka i wsp. 2016). Na podstawie objawów chorobowych na porażonych roślinach pomidora w obrębie szczepu CH2 wyróżniono trzy główne patotypy wirusa: łagodny (niewywołujący objawów lub wywołujący jedynie łagodne zmiany na zielonych częściach roślin), nekrotyczny (powodujący nekrotyczne zmiany na blaszkach liściowych i owocach, często prowadzące do obniżenia plonowania i zamierania roślin) oraz żółtaczkowy (wywołujący objawy zażółcenia liści oraz nekrozy na owocach) (Hasiów-Jaroszewska i wsp. 2009, 2013). Wyka- zano, że pojedyncze substytucje nukleotydów w genomie wirusa mogą w znaczący sposób determinować objawy obserwowane na zainfekowanych roślinach. W przypadku izolatów żółtaczkowych są to dwie niezależne mutacje w genie kodującym białko płaszcza (CP), odpowiednio mutacja w pozycji $463 \mathrm{nt}(155 \mathrm{aa})$ oraz mutacja w pozycji $497 \mathrm{nt}$ (166 aa) (Hasiów-Jaroszewska i wsp. 2013). Pierwsza mutacja $\mathrm{z}_{463} \mathrm{AA}$ do $\mathrm{A}_{463} \mathrm{AA}$, zmienia kwas glutaminowy (E) w lizynę (K), druga natomiast z $\mathrm{GA}_{497} \mathrm{U}$ do $\mathrm{GG}_{497} \mathrm{U}$, skutkuje zmianą kwasu asparaginowego (D) w glicynę (G).

W ostatnich latach na terenie całego kraju obserwowane jest nasilone występowanie wirusa $\mathrm{w}$ wielu obiektach szklarniowych, a także pojawianie się różnych, nowych patotypów, w tym również żółtaczkowych. Objawy na zainfekowanych roślinach mogą przybierać formę jasnożółtej mozaiki obejmującej nawet całe blaszki liściowe (ang. yellow mosaics), jak również pokrywać jedynie niewielkie fragmenty blaszek pomiędzy nerwami (ang. interveinal leaf yellowing symptoms). We wczesnym etapie infekcji, symptomy wywoływane przez izolaty łagodne i żółtaczkowe są bardzo trudne do rozróżnienia. W obu przypadkach infekcja początkowo może być bezobjawowa lub na roślinach można zaobserwować pojedyncze, żółte plamki. Jednakże izolaty żółtaczkowe w odróżnieniu od łagodnych mogą powodować nekrozy na owocach, dlatego bardzo istotne jest ich rozróżnienie we wczesnym etapie infekcji. Co więcej, wiedza z jakim izolatem mamy do czynienia ma znaczenie w kontekście populacyjnym, z uwagi na pojawianie się licznych produktów wykorzystujących łagodne izolaty do ochrony przed bardziej agresywnymi patotypami (zjawisko odporności krzyżowej).

W ostatnich latach w Zakładzie Wirusologii i Bakteriologii Instytutu Ochrony Roślin - Państwowego Instytutu Badawczego pozyskano kolekcje polskich izolatów PepMV charakteryzujące się obecnością objawów żółtaczkowych, pochodzące z upraw szklarniowych pomidora z całego kraju. Celem prowadzonych badań było opracowanie skutecznej metody pozwalającej na rozróżnianie izolatów łagodnych i żółtaczkowych za pomocą techniki ilościowego PCR z analizą krzywych topnienia (qPCR-HRM - quantitative PCR with High Resolution Melting). Analiza HRM opiera się na określeniu zmian fluorescencji spowodowanych topnieniem dwuniciowych produktów PCR, w wyniku wzrostu temperatury. Temperatura topnienia (Tm), a w konsekwencji charakterystyczny kształt profilu krzywej topnienia są wysoce zależne od sekwencji nukleotydów analizowanych produktów. Umożliwia to rozróżnianie poszczególnych patotypów, nawet z pojedynczą substytucją nukleotydów. Technika ta jest obecnie szeroko wykorzystywana do wykrywania i różnicowania patogenów (Bester i wsp. 2012; Hasiów-Jaroszewska i Komorowska 2013; Filipiak i Tomalak 2014). Zastosowanie tej techniki umożliwia 
szybkie rozróżnienie patotypów bez konieczności wykonywania reakcji RT-PCR, a następnie sekwencjonowania uzyskanych produktów.

\section{Materiały i metody / Materials and methods}

Do przeprowadzenia doświadczeń wykorzystano 18 izolatów PepMV zebranych z pomidora pod osłonami na terenie całego kraju. Izolaty te powodowały zróżnicowane objawy chorobowe na roślinach testowych. Były to zarówno bąblowatości liści, łagodne mozaiki, deformacje blaszek oraz żółtaczki (rys. 1). Część izolatów nie wywoływała objawów chorobowych na testowanym materiale (rys. 1). Do badań wybrano 6 izolatów żółtaczkowych, które charakteryzowały się obecnością mutacji $\mathrm{G}_{463} \mathrm{AA} / \mathrm{A}_{463} \mathrm{AA}$ (155 aa) oraz 6 izolatów, które charakteryzowały się obecnością mutacji $\mathrm{GA}_{497} \mathrm{U} / \mathrm{GG}_{497} \mathrm{U}$ (166 aa). Pozostałe 6 izolatów nie posiadało wyżej opisanych mutacji i nie wywoływało znaczących symptomów na roślinach.
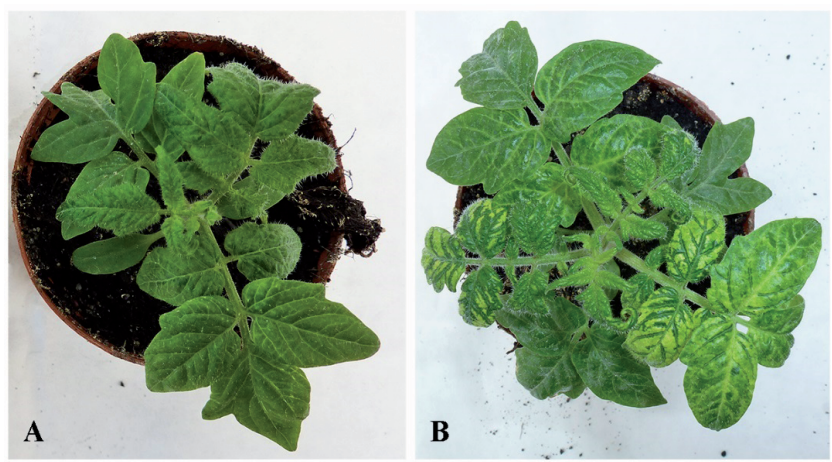

Rys. 1. Objawy na roślinach testowych wywoływane przez różne patotypy wirusa mozaiki pepino: A - łagodne, B - żółtaczkowe

Fig. 1. Symptoms on test plants induced by different PepMV pathotypes: A - mild, B - yellowing

Pozyskanymi izolatami mechanicznie inokulowano rośliny testowe Solanum lycopersicum odmiany Beta lux i po 14 dniach po inokulacji izolowano RNA przy użyciu zestawu RNeasy Plant Mini Kit (Qiagen, Hilden, Germany). Z wyizolowego RNA uzyskiwano cDNA przy użyciu Transcriptor High Fidelity cDNA Synthesis Kit (Sigma-Aldrich, Seelze, Germany) oraz startera oligo (dT) (200 nM), zgodnie z załączoną procedurą. Do przeprowadzenia reakcji qPCR-HRM zaprojektowano cztery pary starterów, które amplifikowały fragment genu kodującego CP, w którym zlokalizowane są obie mutacje żółtaczkowe (tab. 1). Poszczególne startery PepF1-4CP i PepR1-4CP testowano we wszystkich możliwych kombinacjach i w różnych warunkach reakcji (w temperaturze przyłączania starterów od 45 do $60^{\circ} \mathrm{C}$ ). Reakcję przeprowadzono przy
Tabela 1. Startery wykorzystywane do wykonania analizy qPCR-HRM

Table 1. Primers used in qPCR-HRM analysis

\begin{tabular}{l|c}
\hline Starter - Primer & Sekwencja - Sequence 5' $^{\prime} \mathbf{3}^{\prime}$ \\
\hline PepF1CP & CCACACCATCCAACCCTGCTTT \\
\hline PepF4CP & TTTGTCTAGACGTGCACTTGCTG \\
\hline PepF3CP & TCAATATCACACCCAGACAATTCT \\
\hline PepF2CP & GCCAACTGGGCAAAATTGGG \\
\hline PepR1CP & AGACTAGCTGGATTTGTGACTCC \\
\hline PepR3CP & ATTGGGCTGCCTGATTAGG \\
\hline PepR2CP & GGATATTTTCTGGCGGGCAAGGG \\
\hline PepR4CP & GGGTGGTGATGTAGTTGCCAG \\
\hline
\end{tabular}

użyciu zestawu Light Cycler 480 HRM master mix (Roche Diagnostics, Mannheim, Germany) w objętości $20 \mu \mathrm{l}$. Do każdej reakcji wykorzystano $1 \mu$ l odpowiedniego cDNA, $2 \mathrm{mM} \mathrm{MgCl}_{2}, 200 \mathrm{nM}$ poszczególnych starterów oraz $10 \mu \mathrm{l}$ Light Cycler 480 HRM master mix (Roche Diagnostics, Mannheim, Germany). Poszczególne etapy reakcji obejmowały: preinkubację $10 \mathrm{~min} w$ temp. $95^{\circ} \mathrm{C}$ oraz $45 \mathrm{cy}-$ kli amplifikacji (denaturacja $10 \mathrm{~s} \mathrm{w} 95^{\circ} \mathrm{C}$, przyłączanie starterów $15 \mathrm{~s} \mathrm{w}$ temp. od 45 do $60^{\circ} \mathrm{C}$ oraz wydłużanie nici $18 \mathrm{~s}$ w $72^{\circ} \mathrm{C}$ ). Kolejno wykonano analizę HRM w cyklu: $60 \mathrm{~s}$ w $95^{\circ} \mathrm{C}, 60 \mathrm{~s} \mathrm{w} 40^{\circ} \mathrm{C}, 1 \mathrm{~s} \mathrm{w} 65^{\circ} \mathrm{C}$ i $1 \mathrm{~s} \mathrm{w} 97^{\circ} \mathrm{C}$ oraz chłodzenie $30 \mathrm{~s} \mathrm{w} 37^{\circ} \mathrm{C}$. Doświadczenia przeprowadzono przy użyciu dwóch aparatów: Light Cycler 480 II system (Roche Diagnostics, Mannheim, Germany) oraz Light Cycler 96 (Roche Diagnostics, Mannheim, Germany). Uzyskane rezultaty analizowano za pomocą oprogramowania LightCyc$\operatorname{ler}^{\circledR} 96$ SW 1.1 software (Roche, Mannheim, Germany).

\section{Wyniki i dyskusja / Results and discussion}

W przeprowadzonych badaniach wykorzystano reakcję qPCR-HRM w celu wykrycia łagodnych i żółtaczkowych patotypów PepMV. HRM jest obecnie szybko rozwijającą się techniką molekularną umożliwiającą rozróżnianie poszczególnych patotypów na podstawie pojedynczych mutacji występujących pomiędzy nimi (Wittwer i wsp. 2003).

Przeprowadzone badania wykazały, że przy zastosowaniu kombinacji starterów PepF1CP/PepR3CP w temperaturze $55^{\circ} \mathrm{C}$ możliwe jest różnicowanie izolatów łagodnych i żółtaczkowych PepMV. W efekcie zastosowania pary starterów PepF1CP/PepR3CP otrzymano odrębne krzywe topnienia dla izolatów łagodnych $\left(84,38^{\circ} \mathrm{C}\right)$, żółtaczkowych z mutacją $\mathrm{G}_{463} \mathrm{AA} / \mathrm{A}_{463} \mathrm{AA}(155 \mathrm{aa})\left(84,12^{\circ} \mathrm{C}\right)$ i żółtaczkowych z mutacją $\mathrm{GA}_{497} \mathrm{U} / \mathrm{GG}_{497} \mathrm{U}(166 \mathrm{aa})\left(84,65^{\circ} \mathrm{C}\right)$ (rys. 2). Analizowane produkty qPCR-HRM łagodnych i żółtaczkowych patotypów charakteryzowały się dwoma odrębnymi znormalizowanymi krzywymi topnienia, 


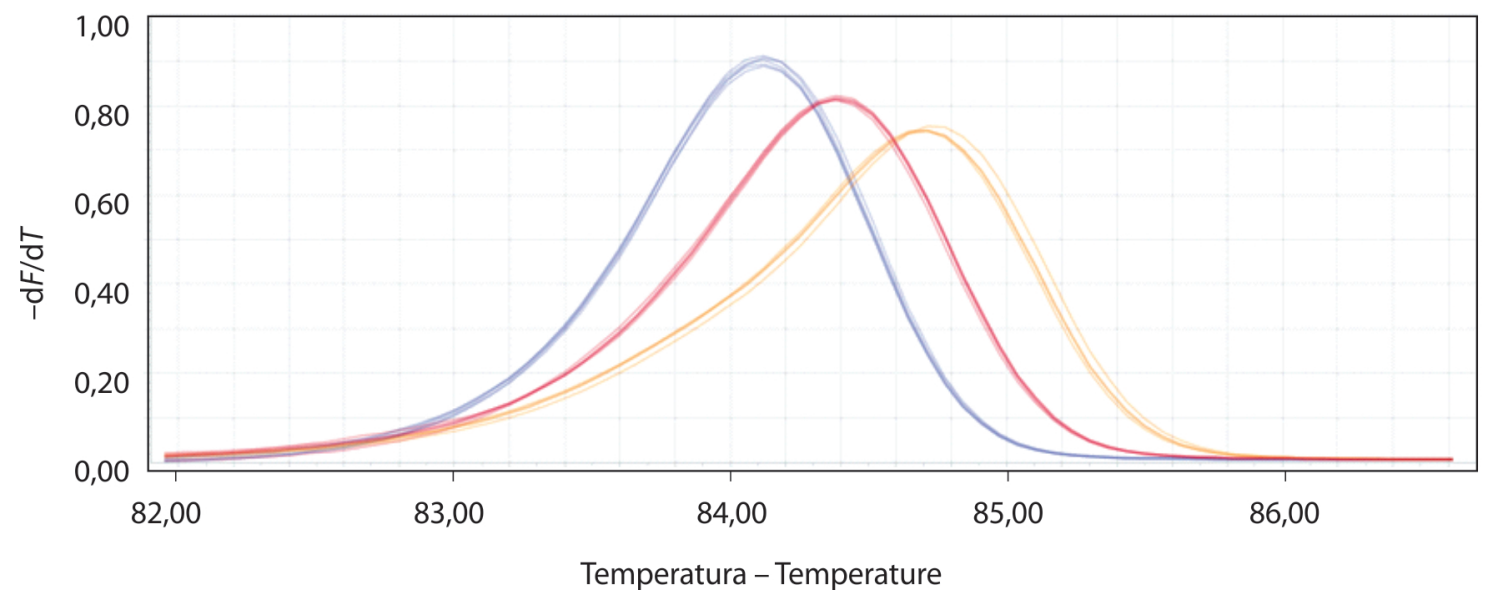

Rys. 2. Krzywe topnienia produktów reakcji qPCR-HRM uzyskanych z wykorzystaniem starterów PepF1CP/PepR3CP dla łagodnych i obu żółtaczkowych izolatów. Kolor niebieski - izolaty z mutacją w pozycji 155 aa, kolor żółty - izolaty z mutacją w pozycji 166 aa, kolor czerwony - izolaty lagodne

Fig. 2. Melting curves of qPCR-HRM products amplified with PepF1CP/PepR3CP primers for mild and yellowing isolates. Blue color isolates with mutation in 155 aa position, yellow color - isolates with mutation in 166 aa position, red color - mild isolates

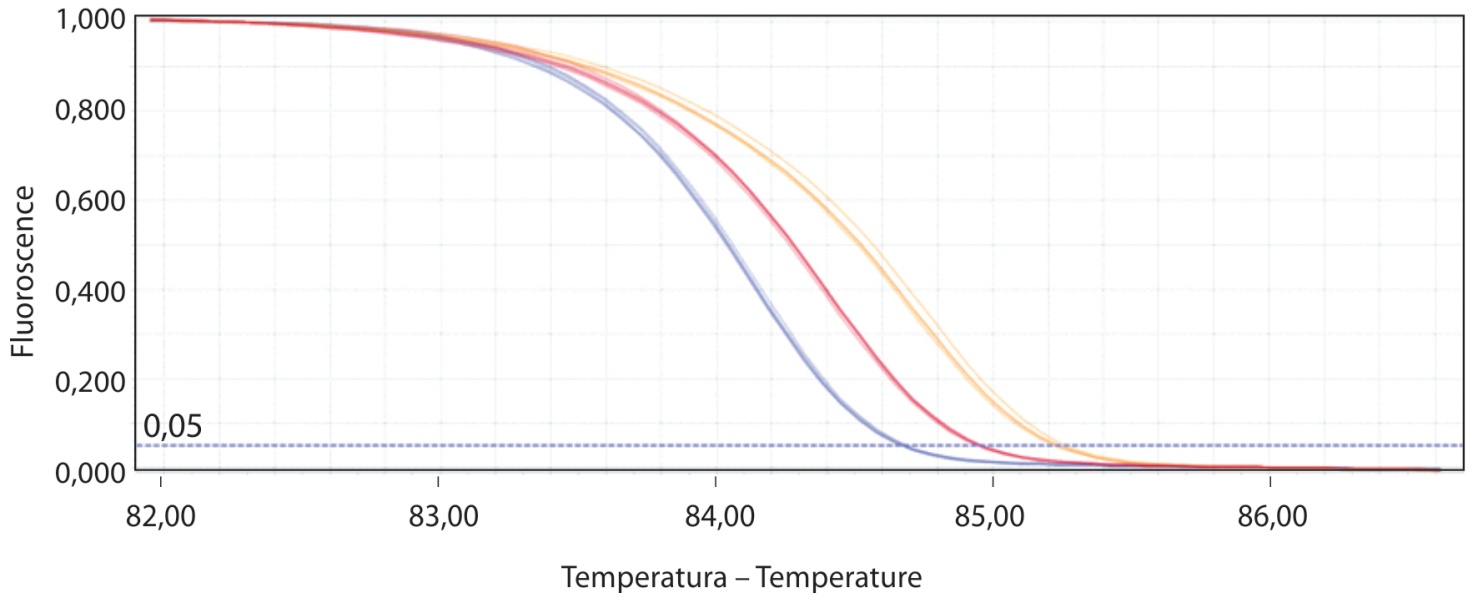

Rys. 3. Znormalizowane krzywe topnienia produktów qPCR -HRM dla łagodnych i żółtaczkowych patotypów. Kolor niebieski - izolaty z mutacją w pozycji 155 aa, kolor żółty - izolaty z mutacją w pozycji 166 aa, kolor czerwony - izolaty łagodne

Fig. 3. Normalized melting curves of qPCR-HRM products for mild and yellowing pathotypes. Blue color - isolates with mutation in 155 aa position, yellow color - isolates with mutation in 166 aa position, red color - mild isolates

o czym świadczą ich znaczne przesunięcia względem siebie (rys. 3).

W przypadku pozostałych starterów, w różnych kombinacjach i różnych warunkach reakcji, uzyskano zbyt małe różnice $\mathrm{w}$ temperaturze topnienia produktów amplifikacji, aby było możliwe rozróżnianie poszczególnych patotypów. Przeprowadzone doświadczenia potwierdziły skuteczność zaprojektowanych starterów do powielania wybranych fragmentów DNA, które umożliwiają odróżnianie patotypów zawierających i niezawierających mutację w genie kodującym CP.

Wyniki uzyskane w przeprowadzonych doświadczeniach dowodzą, że metoda qPCR-HRM może być z powodzeniem wykorzystywana do rozróżniania izolatów łagodnych i żółtaczkowych PepMV. Pozwala to na znacznie szybsze określenie patotypu wirusa $\mathrm{w}$ badanej próbce niż w przypadku zastosowania klasycznej reakcji RT-PCR, a następnie sekwencjonowania. Co więcej, nie ma konieczności przeprowadzania rozdziału uzyskanych produktów amplifikacji w żelu agarozowym, co znacząco skraca czas całej procedury.

\section{Wnioski / Conclusions}

1. Przeprowadzone badania wykazały, że za pomocą reakcji qPCR-HRM możliwe jest szybkie odróżnienie patotypów łagodnych oraz żółtaczkowych, zarówno z mutacją $\mathrm{G}_{463} \mathrm{AA} / \mathrm{A}_{463} \mathrm{AA}(155 \mathrm{aa})$, jak i $\mathrm{GA}_{497} \mathrm{U} / \mathrm{GG}_{497} \mathrm{U}$ (166 aa). 
2. Zastosowanie techniki qPCR-HRM umożliwia znacznie szybsze określenie patotypu wirusa niż to ma miejsce w przypadku zastosowania klasycznej reakcji RT-PCR, a następnie sekwencjonowania.

\section{Literatura / References}

Bester R., Jooste A.E., Maree H.J., Burger J.T. 2012. Real-time RT-PCR high-resolution melting curve analysis and multiplex RT-PCR to detect and differentiate grapevine leafroll-associated virus 3 variant groups I, II, III and VI. Virology Journal 9: 219. DOI: $10.1186 / 1743-422 X-9-219$

Blystad D.R., van der Vlugt R., Alfaro-Fernandez A., Cordoba M.D., Bese G., Hristova D., Pospieszny H., Mehle N., Ravnikar M., Tomassoli L., Varveri C., Nielsen S.L. 2015. Host range and symptomatology of Pepino mosaic virus strains occurring in Europe. European Journal of Plant Pathology 143 (1): 43-56. DOI: 10.1007/s10658-015-0664-1

Córdoba-Sellés M.C., García-Rández A., Alfaro-Fernández A., Jordá-Gutiérrez C. 2007. Seed transmission of Pepino mosaic virus and efficacy of tomato seed disinfection treatments. Plant Disease 91 (10): 1250-1254. DOI: 10.1094/PDIS-91-10-1250

Filipiak A., Tomalak M. 2014. Wykorzystanie techniki PCR-HRM do wykrywania kwarantannowego gatunku nicienia Bursaphelenchus xylophilus. [The use of PCR-HRM technique for detection of the quarantine nematode Bursaphelenchus xylophilus]. Progress in Plant Protection 54 (4): 400-402. DOI: 10.14199/ppp-2014-067

French C.J., Bouthillier M., Bernardy M., Ferguson G., Sabourin M., Johnson R.C., Masters C., Godkin S., Mumford R. 2001. First report of Pepino mosaic virus in Canada and the United States. Plant Disease 85 (10): 1121. DOI: 10.1094/PDIS.2001.85.10.1121B

Gómez P., Sempere R.N., Elena S.F., Aranda M.A. 2009. Mixed infections of Pepino mosaic virus strains modulate the evolutionary dynamics of this emergent virus. Journal of Virology 83 (23): 12378-12387. DOI: 10.1128/JVI.01486-09

Hanssen I.M., Mumford R., Blystad D.R., Cortez I., Hasiów-Jaroszewska B., Hristova D., Pagán I., Pereira A.M., Peters J., Pospieszny H., Ravnikar M., Stijger I., Tomassoli L., Varveri C., van der Vlugt R., Nielsen S.L. 2010. Seed transmission of Pepino mosaic virus in tomato. European Journal of Plant Pathology 126 (2): 145-152. DOI: 10.1007/s10658-009-9528-x

Hanssen I.M., Paeleman A., Vandewoestijne E., Van Bergen L., Bragard C., Lievens B., Vanacher A.C.R.C., Thomma B.P.H.J. 2009. Pepino mosaic virus isolates and differential symptomatology in tomato. Plant Pathology 58 (3): 450-460. DOI: 10.1111/j.13653059.2008.02018.x

Hanssen I.M., Paeleman A., Wittemans L., Goen K., Lievens B., Bragard C., Vanachter A.C.R.C., Thomma B.P.H.J. 2008. Genetic characterization of Pepino mosaic virus isolates from Belgian greenhouse tomatoes reveals genetic recombination. European Journal Plant Pathology 121 (2): 131-146. DOI: 10.1007/s10658-007-9255-0

Hanssen I.M., Thomma B.P.H.J. 2010. Pepino mosaic virus: a successful pathogen that rapidly evolved from emerging to endemic in tomato crops. Molecular Plant Pathology 11 (2): 179-189. DOI: 10.1111/j.1364-3703.2009.00600.x

Hasiów B., Borodynko N., Pospieszny H. 2008. Complete genomic RNA sequence of the Polish Pepino mosaic virus isolate belonging to the US2 strain. Virus Genes 36 (1): 1-8. DOI: 10.1007/s11262-007-0171-3

Hasiów-Jaroszewska B., Jackowiak P., Borodynko N., Figlerowicz M., Pospieszny H. 2010. Quasispecies nature of Pepino mosaic virus and its evolutionary dynamics. Virus Genes 41 (2): 260-267. DOI: 10.1007/s11262-010-0497-0

Hasiów-Jaroszewska B., Komorowska B. 2013. A new method for detection and discrimination of Pepino mosaic virus isolates using high resolution melting analysis of the triple gene block 3. Journal of Virological Methods 193 (1): 1-5. DOI: 10.1016/j. jviromet.2013.04.022

Hasiów-Jaroszewska B., Paeleman A., Ortega-Parra N., Borodynko N., Minicka J., Czerwoniec A., Thomma B.P.H.J., Hanssen I.M. 2013. Ratio of mutated versus wild-type coat protein sequences in Pepino mosaic virus determines the nature and severity of yellowing symptoms on tomato plants. Molecular Plant Pathology 14 (9): 923-933. DOI: 10.1111/mpp.12059

Hasiów-Jaroszewska B., Pospieszny H., Borodynko N. 2009. New necrotic isolates of Pepino mosaic virus representing the CH2 genotype. Journal of Phytopathology 157 (7-8): 494-496. DOI: 10.1111/j.1439-0434.2008.01496.x

Ling K.S. 2007. Molecular characterization of two Pepino mosaic virus variants from imported tomato seed reveals high levels of sequence identity between Chilean and US isolates. Virus Genes 34 (1): 1-8. DOI: 10.1007/s11262-006-0003-x

Ling K., Li R., Bledsoe M. 2013. Pepino mosaic virus genotype shift in North America and development of a loop-mediated isothermal amplification for rapid genotype identification. Virology Journal 10: 117. DOI: 10.1186/1743-422X-10-117

Maroon-Lango C.J., Guaragna M.A., Jordan R.L., Hammond J., Bandla M., Marquardt S.K. 2005. Two unique US isolates of Pepino mosaic virus from a limited source of pooled tomato tissue are distinct from a third (European-like) US isolate. Archives of Virology 150 (6): 1187-1201. DOI: 10.1007/s00705-005-0495-z

Mehle N., Gutierrez-Aguirre I., Prezelj N., Delić D., Vidic U., Ravnikar M. 2014. Survival and transmission of Potato virus Y, Pepino mosaic virus, and Potato spindle tuber viroid in water. Applied and Environmental Microbiology 80 (4): 1455-1462. DOI: 10.1128/ AEM.03349-13

Minicka J., Hasiów-Jaroszewska B., Borodynko-Filas N., Pospieszny H., Hanssen I.M. 2016. Rapid evolutionary dynamics of the Pepino mosaic virus - status and future perspectives. Journal of Plant Protection Research 56 (4): 337-345. DOI: 10.1515/jppr-2016-0054

Moreno-Pérez M.G., Pagán I., Aragón-Caballero L., Cáceres F., Fraile A., García-Arenal F. 2014. Ecological and genetic determinants of Pepino mosaic virus emergence. Journal of Virology 88 (6): 3359-3368. DOI: 10.1128/JVI.02980-13

Noël P., Hance T., Bragard A.C. 2014. Transmission of the Pepino mosaic virus by whitefly. European Journal of Plant Pathology 138 (1): 23-27. DOI: 10.1007/s10658-013-0313-5

Pospieszny H., Borodynko N., Palczewska M. 2003. First record of Pepino mosaic virus in Poland. Journal of Plant Disease Protection 100: 97.

Roggero P., Masenga V., Lenzi R., Coghe F., Ena S., Winter S. 2001. First report of Pepino mosaic virus in tomato in Italy. Plant Pathology 50 (6): 798. DOI: 10.1046/j.1365-3059.2001.00621.x 
Schwarz D., Beuch U., Bandte M., Fakhro A., Büttner C., Obermeier C. 2010. Spread and interaction of Pepino mosaic virus (PepMV) and Pythium aphanidermatum in a closed nutrient solution recirculation system: effects on tomato growth and yield. Plant Pathology 59 (3): 443-452. DOI: 10.1111/j.1365-3059.2009.02229.x

Shipp J.L., Buitenhuis R., Stobbs L., Wang K., Kim W.S., Ferguson G. 2008. Vectoring of Pepino mosaic virus by bumblebees in tomato greenhouses. Annals of Applied Biology 153 (2): 149-155. DOI: 10.1111/j.1744-7348.2008.00245.x

Spence N.J., Basham J., Mumford R.A., Hayman G., Edmondson R., Jones D.R. 2006. Effect of Pepino mosaic virus on the yield and quality of glasshouse-grown tomatoes in the UK. Plant Pathology 55 (5): 595-606. DOI: 10.1111/j.1365-3059.2006.01406.x

Tiberini A., Davino S., Davino M., Tomassoli L. 2011. Complete sequence, genotyping and comparative analysis of Pepino mosaic virus isolates from Italy. Journal of Plant Pathology 93 (2): 437-442. DOI: 10.4454/jpp.v93i2.1199

van der Vlugt R.A., Stijger C.M., Verhoeven J.T.J., Lesemann D.E. 2000. First report of Pepino mosaic virus on tomato. Plant Disease 84 (1): 103-108. DOI: 10.1094/PDIS.2000.84.1.103C

Wittwer C.T., Reed G.H., Gundry C.N., Vandersteen J.G., Pryor R.J. 2003. High-resolution genotyping by amplicon melting analysis using LCGreen. Clinical Chemistry 49 (6): 853-860. DOI: 10.1373/49.6.853 